\title{
PERANCANGAN PENGUKURAN TEGANGAN TINGGI PADA MODUL PEMBANGKIT TEGANGAN TINGGI IMPULS
}

\author{
Chyntia Dewi Candra Pravitasari*) ${ }^{*}$, Abdul Syakur, and Budi Setiyono \\ Departemen Teknik Elektro, Universitas Diponegoro \\ J1. Prof. Sudharto, SH, Kampus UNDIP Tembalang, Semarang 50275, Indonesia \\ ${ }^{*}$ E-mail : chyntiadewi96@gmail.com
}

\begin{abstract}
Abstrak
Pengukuran tegangan tinggi AC, DC dan Impuls pada skala laboratorium menggunakan alat ukur yang harganya mahal. Disamping itu, pengukuran yang dilakukan yaitu pada tingkat tegangan $15 \mathrm{KV}$. Pengukuran tegangan tinggi AC, DC dan Impuls secara terintegrasi untuk tingkat tegangan $15 \mathrm{KV}$ dengan menggunakan trafo sign belum pernah dilakukan. Padahal pembangkitan tegangan tinggi dengan menggunakan trafo sign hanya mampu membangkitkan tegangan hingga tegangan $15 \mathrm{KV}$ saja. Untuk itu dibutuhkan sebuah alat ukur tegangan yang mampu mengukur hingga tegangan $15 \mathrm{KV}$, dan tidak memakan biaya yang mahal. Pada penelitian ini akan dirancang sebuah sistem monitoring tegangan tinggi pada modul pembangkit tegangan tinggi impuls dengan menggunakan visual studio $\mathrm{c \# .} \mathrm{Hasil} \mathrm{pengujian} \mathrm{monitoring} \mathrm{modul}$ pembangkit tegangan tinggi pada form visual studio $\mathrm{c} \#$ berhasil berjalan dengan baik. Pengujian tegangan yang dilakukan menghasilkan nilai yang mendekati nilai sebenarnya dengan error rata-rata 0.01 volt. Sayangnya pengujian ini masih belum bisa dikatakan sempurna karena masih rentan terhadap noise sehingga proses pengukuran sering terganggu.
\end{abstract}

Kata kunci : Tegangan Tinggi, monitoring data, visual studio c\#

\begin{abstract}
Measurement of high voltage AC, DC and Impulses on a laboratory scale using expensive measuring instruments. In addition, the measurements taken are at a voltage level of $15 \mathrm{KV}$. Integrated measurement of high voltage AC, DC and Impulses for $15 \mathrm{KV}$ voltage levels using sign transformers has never been done. Whereas high voltage generation using a sign transformer is only able to generate voltage up to $15 \mathrm{KV}$ voltage only. For that we need a voltage measuring device that is able to measure up to a voltage of $15 \mathrm{KV}$, and does not require expensive costs. In this Final Project, a high voltage monitoring module for impulse high voltage generator module will be designed using visual studio $\mathrm{c} \#$. The results of monitoring the high voltage generator module on the $\mathrm{C} \#$ visual studio form successfully went well. The voltage test performed produces a value close to the actual value with an average error of 0.01 volts. Unfortunately this test is still not perfect because it is still susceptible to noise so that the measurement process is often interrupted.
\end{abstract}

Keywords: High Voltage, monitoring, visual studio c\#

\section{Pendahuluan}

Pengetahuan mengenai tegangan tinggi telah mengalami perkembangan yang pesat. Terdapat tiga jenis tegangan tinggi yaitu tegangan tinggi bolak-balik (AC), tegangan tinggi searah (DC), dan tegangan tinggi impuls. Studi mengenai tegangan tinggi memiliki cakupan yang cukup luas, seperti pembangkitan tegangan tinggi,pengukuran tegangan tinggi, dan lain-lain [1]. Tegangan tinggi memiliki berbagai fungsi dan manfaat antara lain untuk sumber tenaga listrik, kebutuhan studi dan penelitian di laboratorium, dan lain sebagainya [2].

Pada skala laboratorium, modul pembangkit tegangan tinggi AC, DC dan Impuls membutuhkan alat ukur yang presisi. Selama ini, alat ukur yang sudah ada dibuat secara pabrikan yang mana harganya relatif mahal. Disamping itu, pengukuran yang biasanya dilakukan yaitu pada tingkat tegangan sampai $100 \mathrm{KV}$ [3]. Pengukuran tegangan tinggi AC, DC dan Impuls secara terintegrasi untuk tingkat tegangan $15 \mathrm{KV}$ dengan menggunakan trafo sign belum pernah dilakukan. Padahal pembangkitan tegangan tinggi dengan menggunakan trafo sign hanya mampu membangkitkan tegangan hingga tegangan $15 \mathrm{KV}$ saja. Untuk itu dibutuhkan sebuah alat ukur tegangan yang mampu mengukur hingga tegangan $15 \mathrm{KV}$, dan tidak memakan biaya yang mahal.

Berdasarkan permasalahan diatas, penelitian ini dilakukan untuk merancang sebuah sistem monitoring tegangan tinggi pada modul pembangkit tegangan tinggi dengan menggunakan trafo sign. Pengukuran yang dilakukan 
diharapkan mampu menghasilkan nilai yang menyerupai nilai sebenarnya [4][5].

\section{Metode}

Perancangan penelitian ini terdiri dari rangkaian pengukuran $\mathrm{AC}$, rangkaian pengukuran dc, rangkaian pengukuran Impuls dan HMI. Sistem perancangan penelitian secara umum dapat dilihat pada Gambar 1.

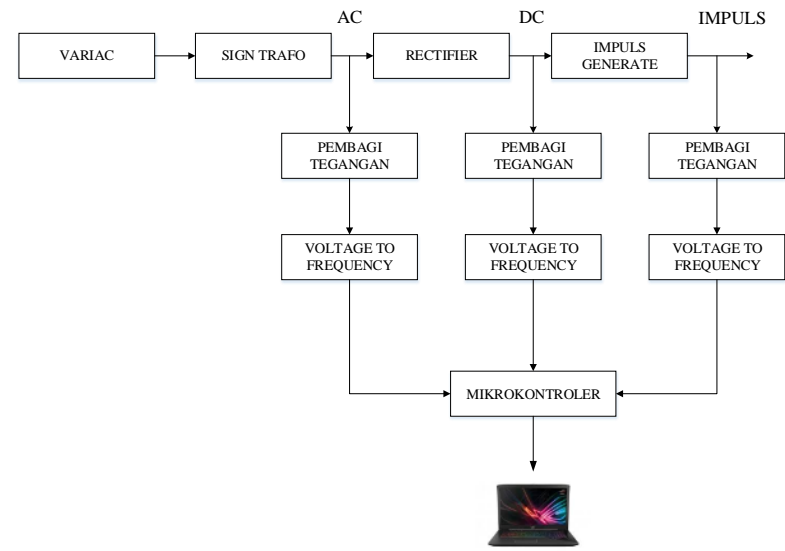

Gambar 1. Diagram blok alat secara keseluruhan.

\subsection{Pengukuran Tegangan AC}

Pada pengukuran tegangan AC digunakan metode pembagi tegangan untuk menurunkan tegangannya. Pembagi tegangan yang digunakan yaitu dengan perbandingan 20.000 : 1. Setelah melalui pembagi tegangan kemudian tegangan akan masuk ke rangkaian voltage to frequency untuk selanjutnya di teruskan untuk pembacaan di mikrokontroler

\section{A. Pembagi Tegangan (Voltage Divider)}

Pembagi tegangan yang digunakan dalam pengukuran tegangan AC yaitu dengan resistor $1 \mathrm{G} \Omega$ sebagai resistor atas dan resistor $50 \mathrm{~K} \Omega$ sebagai resistor bawah (Rshunt). Pembuatan resistor $1 \mathrm{G} \Omega$ yaitu dengan merangkai seri 100 buah resistor berukuran $10 \mathrm{M} \Omega$.

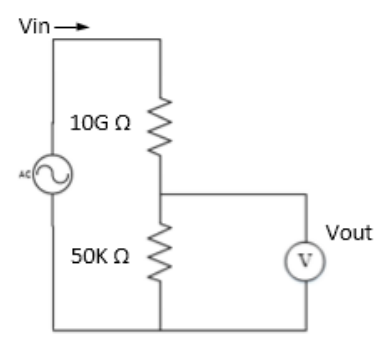

Gambar 2. Diagram blok alat secara keseluruhan.

Berdasarkan rangkaian pada Gambar 2, perhitungan untuk keluaran (Vout) dari pembaginya adalah sebagai berikut :
Vout $=\frac{R 1}{R 1+R 2} x$ Vin

Misalkan diberi Vin $1000 \mathrm{~V}$, hasil perhitungannya adalah sebagai berikut :

$$
\begin{aligned}
\text { Vout } & =\frac{1 G}{1 G+50 K} \times 1000 \\
& \approx 0.049 \mathrm{~V}
\end{aligned}
$$

Vin merupakan tegangan input yang dihasilkan dari sign trafo sedangkan Vout merupakan tegangan keluaran dari pembacaan pembagi tegangan. Pengujian Vout pembagi tegangan dilakukan dengan rentang Vin antara $1 \mathrm{KV}-10$ KV. Hasil pengujian dapat dilihat pada Tabel 1

Tabel 1. Tabel pengujian Vout pembagi tegangan AC.

\begin{tabular}{cccc}
\hline Variac & Vin & \multicolumn{2}{c}{ Vout } \\
\cline { 3 - 4 } & & Perhitungan & $\begin{array}{c}\text { Pembagi } \\
\text { Tegangan }\end{array}$ \\
\hline $16.75 \mathrm{~V}$ & $1 \mathrm{KV}$ & $0.049 \mathrm{~V}$ & $0.16 \mathrm{~V}$ \\
$30.64 \mathrm{~V}$ & $2 \mathrm{KV}$ & $0.099 \mathrm{~V}$ & $0.29 \mathrm{~V}$ \\
$44.94 \mathrm{~V}$ & $3 \mathrm{KV}$ & $0.149 \mathrm{~V}$ & $0.43 \mathrm{~V}$ \\
$58.86 \mathrm{~V}$ & $4 \mathrm{KV}$ & $0.199 \mathrm{~V}$ & $0.56 \mathrm{~V}$ \\
$73.16 \mathrm{~V}$ & $5 \mathrm{KV}$ & $0.249 \mathrm{~V}$ & $0.7 \mathrm{~V}$ \\
$88.98 \mathrm{~V}$ & $6 \mathrm{KV}$ & $0.299 \mathrm{~V}$ & $0.84 \mathrm{~V}$ \\
$102.99 \mathrm{~V}$ & $7 \mathrm{KV}$ & $0.399 \mathrm{~V}$ & $0.98 \mathrm{~V}$ \\
$116.18 \mathrm{~V}$ & $8 \mathrm{KV}$ & $0.449 \mathrm{~V}$ & $1.12 \mathrm{~V}$ \\
$130.32 \mathrm{~V}$ & $9 \mathrm{KV}$ & $0.499 \mathrm{~V}$ & $1.31 \mathrm{~V}$ \\
$143.84 \mathrm{~V}$ & $10 \mathrm{KV}$ & $0.549 \mathrm{~V}$ & $1.4 \mathrm{~V}$ \\
\hline
\end{tabular}

Dari Tabel 1 diatas dapat dilihat bahwa hasil Vout perhitungan dan Vout pembagi tegangan memiliki perbedaan yang sangat jauh. Perbedaan terjadi dikarenakan tegangan AC sangat tidak stabil. Selain itu, ketika pengujian dilakukan beban AC pada supply PLN yang digunakan besar sehingga terjadi drop tegangan. Keluaran dari pembagi tegangan AC selanjutnya akan masuk ke rangkaian voltage to frequency converter.

\section{B. Voltage to Frequency Converter (V to F) Tegangan $\mathrm{AC}$}

Pada implementasinya penggunaan pembagi tegangan saja masih dapat merusak mikrokontroler apabila langsung dihubungkan, terlebih dengan tegangan AC yang mudah terjadi breakdown. Hal ini dikarenakan pembagi tegangan belum memberikan isolasi terhadap rangkaian yang dihubungkan. Oleh karena itu dibutuhkan sebuah isolasi yang dapat melindungi rangkaian dari karusakan akibat tegangan tinggi. Untuk pengisolasian digunakan optocoupler atau yang biasa disebut optoisolator [6]

Pada penggunaannya, optocoupler hanya bekerja dengan mengenal dua keadaan saja, yaitu HIGH dan LOW, sehingga tidak bisa digunakan untuk proses pembacaan nilai analog. Dibutuhkan rangkaian tambahan berupa $\mathrm{V}$ to $\mathrm{F}$ untuk dapat mengatasi hal ini. $\mathrm{V}$ to $\mathrm{F}$ akan mengubah nilai tegangan menjadi frekuensi digital yang nilainya akan berubah sesuai dengan tegangan yang terbaca, sehingga bisa dihubungkan untuk pembacaan tegangan secara 
terisolasi melalui optocoupler. Rangkaian $\mathrm{V}$ to $\mathrm{F}$ untuk tegangan AC dapat dilihat pada Gambar 3.

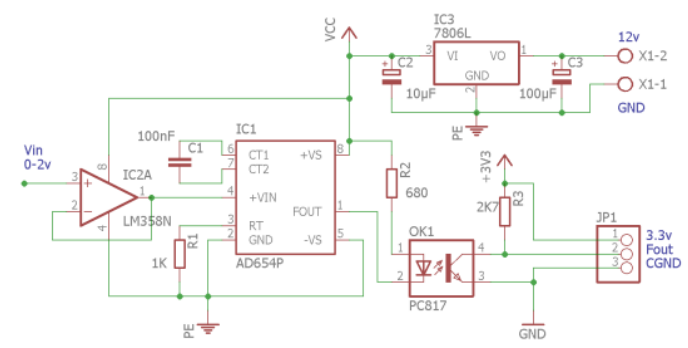

Gambar 3. Rangkaian Voltage to Frequency Tegangan AC.

Pada pengujian $\mathrm{V}$ to $\mathrm{F}$ pada tegangan $\mathrm{AC}$ digunakan sebuah dioda yang diseri dengan pembagi tegangan. Hal ini dikarenakan pada tegangan AC terdapat beda fasa sehingga perlu untuk disearahkan terlebih dahulu. Pengujian dilakukan dengan memberi inputan dari pembagi tegangan (Vdiv). Hasil pengujian dapat dilihat pada Tabel 2.

Tabel 2. Hasil pengujian $\mathrm{V}$ to $\mathrm{F}$ pada tegangan $\mathrm{AC}$.

\begin{tabular}{lll}
\hline Variac & Vdiv & Frekuensi \\
\hline $16.75 \mathrm{~V}$ & $0.16 \mathrm{~V}$ & $250.4 \mathrm{~Hz}$ \\
$30.64 \mathrm{~V}$ & $0.29 \mathrm{~V}$ & $326.1 \mathrm{~Hz}$ \\
$44.94 \mathrm{~V}$ & $0.43 \mathrm{~V}$ & $328.6 \mathrm{~Hz}$ \\
$58.86 \mathrm{~V}$ & $0.56 \mathrm{~V}$ & $416.1 \mathrm{~Hz}$ \\
$73.16 \mathrm{~V}$ & $0.7 \mathrm{~V}$ & $537.9 \mathrm{~Hz}$ \\
$88.98 \mathrm{~V}$ & $0.84 \mathrm{~V}$ & $688.6 \mathrm{~Hz}$ \\
\hline
\end{tabular}

Pengujian $\mathrm{V}$ to $\mathrm{F}$ dengan tegangan $\mathrm{AC}$ hanya dapat dilakukan sampai dengan tegangan Vdiv 0.84 atau $6 \mathrm{KV}$ saja. Hal ini dikarenakan terjadi breakdown atau tegangan loncat pada sisi VtoF. Dengan demikian alat yang sudah dirancang tidak dapat digunakan dalam proses pengukuran tegangan. Untuk mengatasi permasalahan ini, maka pengukuran $\mathrm{AC}$ akan dilakukan berdasarkan perhitungan antara Vvar dan Vout dari tegangan AC tanpa pembagi tegangan. Data hasil pengujian antara variac dan keluaran tegangan AC dapat dilihat pada Tabel 3.

Tabel 3. Hasil pengujian keluaran tegangan AC dengan variac.

\begin{tabular}{cc}
\hline Variac & Output AC \\
\hline $16.75 \mathrm{~V}$ & $1 \mathrm{KV}$ \\
$30.64 \mathrm{~V}$ & $2 \mathrm{KV}$ \\
$44.94 \mathrm{~V}$ & $3 \mathrm{KV}$ \\
$58.86 \mathrm{~V}$ & $4 \mathrm{KV}$ \\
$73.16 \mathrm{~V}$ & $5 \mathrm{KV}$ \\
$88.98 \mathrm{~V}$ & $6 \mathrm{KV}$ \\
$102.99 \mathrm{~V}$ & $7 \mathrm{KV}$ \\
$116.18 \mathrm{~V}$ & $8 \mathrm{KV}$ \\
$130.32 \mathrm{~V}$ & $9 \mathrm{KV}$ \\
$143.84 \mathrm{~V}$ & $10 \mathrm{KV}$ \\
$162.45 \mathrm{~V}$ & $11 \mathrm{KV}$ \\
$175.41 \mathrm{~V}$ & $12 \mathrm{~V}$ \\
\hline
\end{tabular}

Data yang terdapat pada Tabel 3 akan diolah sesuai dengan karakteristik pada sign trafo untuk mendapatkan hasil pengukuran AC.

\subsection{Pengukuran Tegangan DC}

Pada pengukuran tegangan DC digunakan metode pembagi tegangan untuk menurunkan tegangannya. Pembagi tegangan yang digunakan yaitu dengan perbandingan $10.000: 1$. Setelah melalui pembagi tegangan kemudian tegangan akan masuk ke voltage to frequency untuk selanjutnya di teruskan untuk pembacaan di mikrokontroler.

\section{A. Pembagi Tegangan (Voltage Divider)}

Pembagi tegangan yang digunakan dalam pengukuran tegangan DC terdiri dari resistor $1 \mathrm{G} \Omega$ sebagai resistor atas dan resistor $100 \mathrm{~K} \Omega$ sebagai resistor bawah (Rshunt). Pembuatan resistor $1 \mathrm{G} \Omega$ yaitu dengan merangkai seri 100 buah resistor berukuran $10 \mathrm{M} \Omega$.

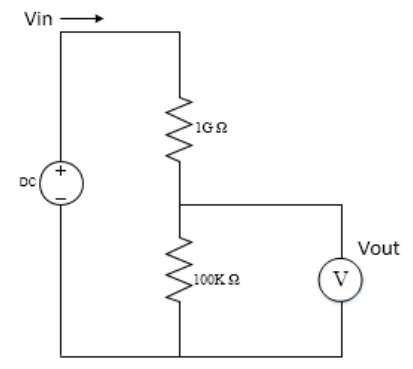

Gambar 4. Rangkaian pembagi tegangan DC.

Berdasarkan rangkaian pada Gambar 4, perhitungan untuk keluaran dari pembaginya [7] adalah sebagai berikut :

Vout $=\frac{R 1}{R 1+R 2} x$ Vin

Contoh perhitungan dengan Vin $2000 \mathrm{~V}$ adalah sebagai berikut :

$$
\begin{aligned}
\text { Vout } & =\frac{1 G}{1 G+100 K} \times 2000 \\
& \approx 0.19 \mathrm{~V}
\end{aligned}
$$

Vin merupakan tegangan input yang dihasilkan dari keluaran sign trafo sedangkan Vout merupakan tegangan keluaran dari pembacaan pembagi tegangan. Pengujian keluaran pembagi tegangan dilakukan dengan rentang Vin antara $2 \mathrm{KV}-14 \mathrm{KV}$. Hasil pengujian dapat dilihat pada Tabel 4.

Tabel 4. Tabel pengujian Vout pembagi tegangan DC.

\begin{tabular}{cccc}
\hline Variac & Vin & Vout \\
\cline { 3 - 4 } & & Perhitungan & $\begin{array}{c}\text { Pembagi } \\
\text { Tegangan }\end{array}$ \\
\hline $21.59 \mathrm{~V}$ & $2 \mathrm{KV}$ & $0.19 \mathrm{v}$ & $0.15 \mathrm{~V}$ \\
$47.77 \mathrm{~V}$ & $4 \mathrm{KV}$ & $0.39 \mathrm{~V}$ & $0.36 \mathrm{~V}$ \\
$73.76 \mathrm{~V}$ & $6 \mathrm{KV}$ & $0.59 \mathrm{~V}$ & $0.56 \mathrm{~V}$ \\
$97.57 \mathrm{~V}$ & $8 \mathrm{KV}$ & $0.79 \mathrm{~V}$ & $0.75 \mathrm{~V}$ \\
$122.22 \mathrm{~V}$ & $10 \mathrm{KV}$ & $0.99 \mathrm{~V}$ & $0.95 \mathrm{~V}$ \\
$146.87 \mathrm{~V}$ & $12 \mathrm{KV}$ & $1.2 \mathrm{v}$ & $1.16 \mathrm{~V}$ \\
$171.98 \mathrm{~V}$ & $14 \mathrm{KV}$ & $1.4 \mathrm{~V}$ & $1.36 \mathrm{~V}$ \\
\hline
\end{tabular}


Dari Tabel 4 diatas dapat dilihat bahwa hasil Vout perhitungan dan Vout pembagi tegangan memiliki perbedaan rata-rata sekitar $0.04 \mathrm{v}$. Perbedaan yang terjadi dikarenakan nilai toleransi pada resistor dan factor-faktor pengujan lainnya. Keluaran dari pembagi tegangan DC yang dihasilkan berkisar antara 0.19-1.4 sehingga dapat menjadi inputan pada voltage to frequency converter yang mana memiliki kemampuan menerima tegangan $0-2 \mathrm{~V}$.

\section{B. Voltage to Frequency Converter (V to F) Tegangan DC}

Pada implementasinya penggunaan pembagi tegangan saja masih dapat merusak mikrokontroler apabila langsung dihubungkan. Hal ini dikarenakan pembagi tegangan masih menggunakan jalur ground yang sama dengan sistem sehingga tidak bisa memberikan isolasi. Maka dari itu dibutuhkan rangkaian dengan jalur ground yang berbeda dengan sistem. Untuk pengisolasian diperlukan optocoupler atau yang biasa disebut optoisolator.

Pada penggunaannya, optocoupler hanya bekerja dengan mengenal dua keadaan saja, yaitu HIGH dan LOW, sehingga tidak bisa digunakan untuk proses pembacaan nilai analog. Dibutuhkan rangkaian tambahan berupa $\mathrm{V}$ to $\mathrm{F}$ untuk dapat mengatasi hal ini. $\mathrm{V}$ to $\mathrm{F}$ akan mengubah nilai tegangan menjadi frekuensi digital yang nilai frekuensinya akan berubah sesuai dengan tegangan yang terbaca [8], sehingga bisa dihubungkan untuk pembacaan tegangan secara terisolasi melalui optocoupler.

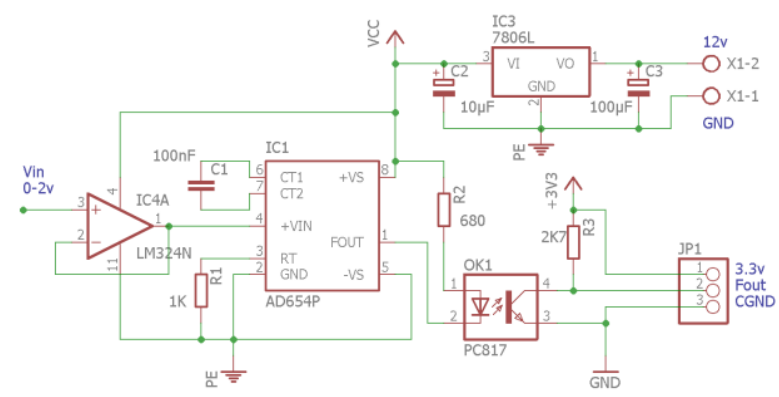

Gambar 5. Rangkaian Voltage to Frequency Tegangan DC.

Hasil pengujian frekuensi voltage to frequency dapat dilihat pada Tabel 5 .

Tabel 5. Hasil pengujian rangkaian vtof.

\begin{tabular}{ccc}
\hline \multirow{2}{*}{ Vdiv } & \multicolumn{2}{c}{ Frekuensi } \\
\cline { 2 - 3 } & DC Supply & Pembagi Tegangan \\
\hline $0.15 \mathrm{v}$ & $161.9 \mathrm{~Hz}$ & $164.7 \mathrm{~Hz}$ \\
$0.36 \mathrm{v}$ & $372.7 \mathrm{~Hz}$ & $374.3 \mathrm{~Hz}$ \\
$0.56 \mathrm{v}$ & $582.1 \mathrm{~Hz}$ & $583.9 \mathrm{~Hz}$ \\
$0.75 \mathrm{v}$ & $768.2 \mathrm{~Hz}$ & $781.2 \mathrm{~Hz}$ \\
$0.95 \mathrm{v}$ & $967.3 \mathrm{~Hz}$ & $967.3 \mathrm{~Hz}$ \\
$1.16 \mathrm{v}$ & $1.174 \mathrm{KHz}$ & $1.174 \mathrm{KHz}$ \\
$1.36 \mathrm{v}$ & $1.366 \mathrm{KHz}$ & $1.377 \mathrm{z}$ \\
\hline
\end{tabular}

Dari Tabel 5 diatas dapat diamati bahwa hasil pengujian dengan DC supply dan pembagi tegangan hampir serupa.
Dengan ini dapat dikatakan bahwa rangkaian $\mathrm{V}$ to $\mathrm{F}$ dapat digunakan bersamaan dengan rangkaian pembagi tegangan. Hasil keluaran frekuensi inilah yang nantinya akan diolah untuk pembacaan nilai tegangan DC

\subsection{Pengukuran Tegangan Impuls}

Pada tegangan impuls, digunakan pembagi tegangan dan rangkaian voltage to frequency converter yang sama seperti pada pengukuran tegangan DC. Hal ini dikarenakan tegangan impuls terjadi pada saat tegangan DC disambungkan ke elektroda kemudian diberi beban berupa resistor dan kapasitor. Resistor yang digunakan yaitu resistor batu $680 \mathrm{~K} \Omega$

Hasil pengukuran tegangan impuls yang dilakukan dengan osiloskop dengan probe tegangan tinggi didapatkan hasil seperti pada gambar 6

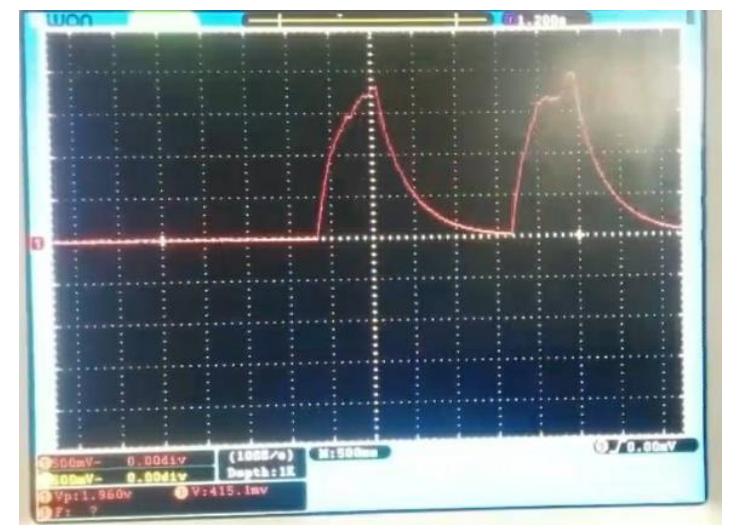

Gambar 6. Tegangan impuls dengan resistor $680 \mathrm{~K} \Omega$

Pada pengujian dengan probe tegangan tinggi diketahui bahwa tegangan impuls dengan resistor $680 \mathrm{~K} \Omega$ terjadi pada saat tegangan DC memiliki nilai antara $10.9 \mathrm{KV}-11$ KV dengan tegangan keluaran variac berkisar antara 128$138 \mathrm{~V}$. Tegangan yang dihasilkan pada saat tegangan impuls mencapai puncak yaitu $1.96 \mathrm{KV}-2 \mathrm{KV}$.

\subsection{Perancangan Perangkat Lunak}

Perancangan perangkat lunak meliputi perancangan senarai program yang ada pada mikrokontroler sesuai dengan algoritma yang telah ditentukan, serta perancangan sebuah HMI (Human Machine Interface) dengan menggunakan bahasa pemrograman berbasis visual $\mathrm{C \#}$. Gambar 7 menunjukkan diagram alir (flowchart) dari perangkat lunak yg dirancang.

Perancangan interface pada penelitian ini bertujuan sebagai sistem antarmuka antara user dan modul tegangan tinggi [9]. Dengan adanya interface ini, user dapat melakukan pengendalian serta memonitoring tegangan keluaran dari sign transformator. Perancangan sistem interface menggunakan bahasa pemrograman $\mathrm{C \#}$ pada 
Microsoft Visual Studio 2015. Pengambilang data yang digunakan pada interface ini menggunakan metode parsing data. Metode parsing data adalah mengirimkan variabel alfabet dalam setiap baris yang dikirim unuk membedakan berbagai macam data yang akan diolah. Tampilan HMI yang telah dibuat untuk proses akuisisi data terdiri dari form Login dan form Main.
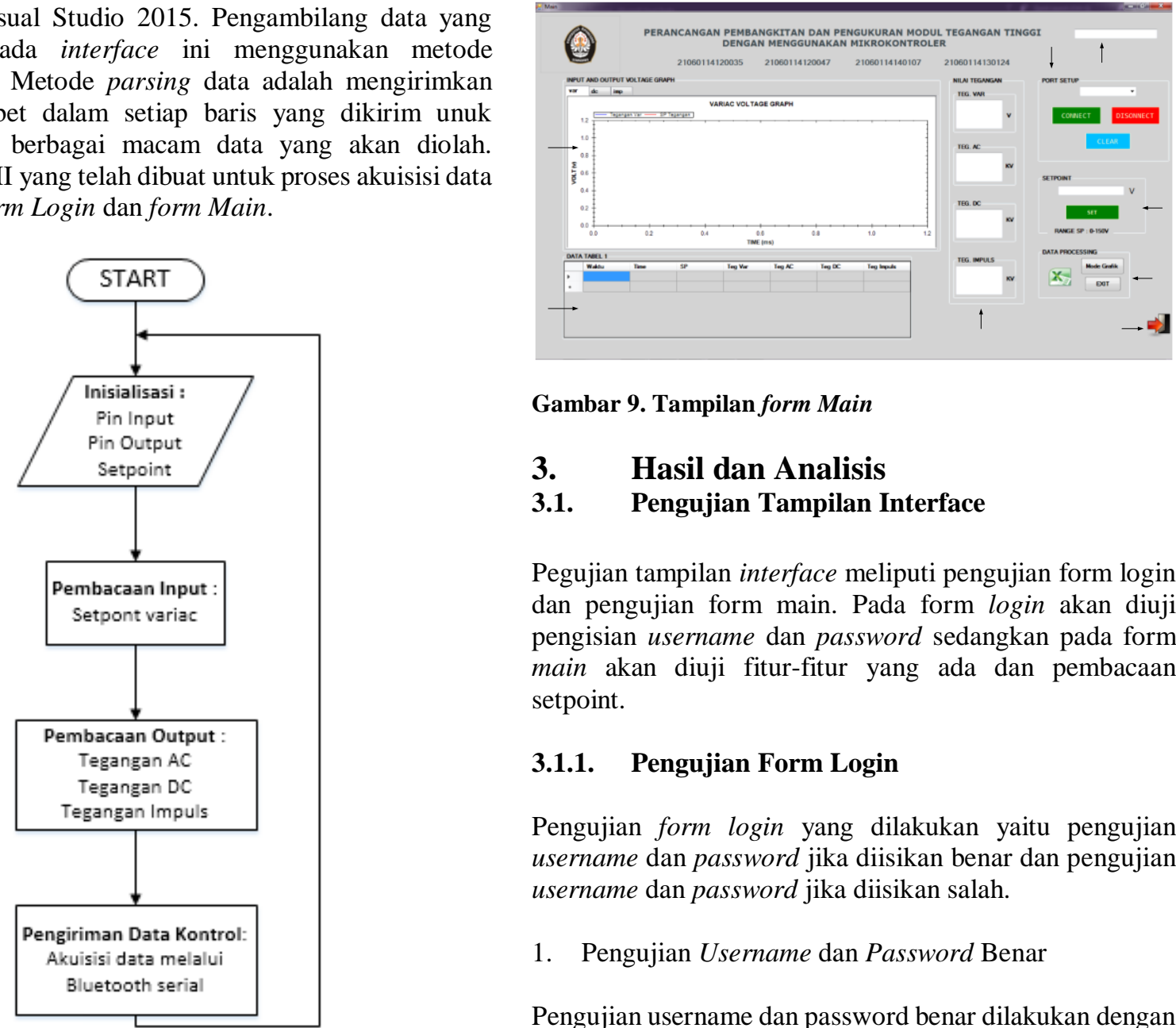

Gambar 9. Tampilan form Main

\section{Hasil dan Analisis \\ 3.1. Pengujian Tampilan Interface}

Pegujian tampilan interface meliputi pengujian form login dan pengujian form main. Pada form login akan diuji pengisian username dan password sedangkan pada form main akan diuji fitur-fitur yang ada dan pembacaan setpoint.

\subsubsection{Pengujian Form Login}

Pengujian form login yang dilakukan yaitu pengujian username dan password jika diisikan benar dan pengujian username dan password jika diisikan salah.

\section{Pengujian Username dan Password Benar}

Pengujian username dan password benar dilakukan dengan mengisikan username dan password yang sesuai. Hasil dari pengujian username dan password benar ditunjukkan pada Gambar 10.

\section{Gambar 7. Diagram alir (flowchart) perangkat lunak}

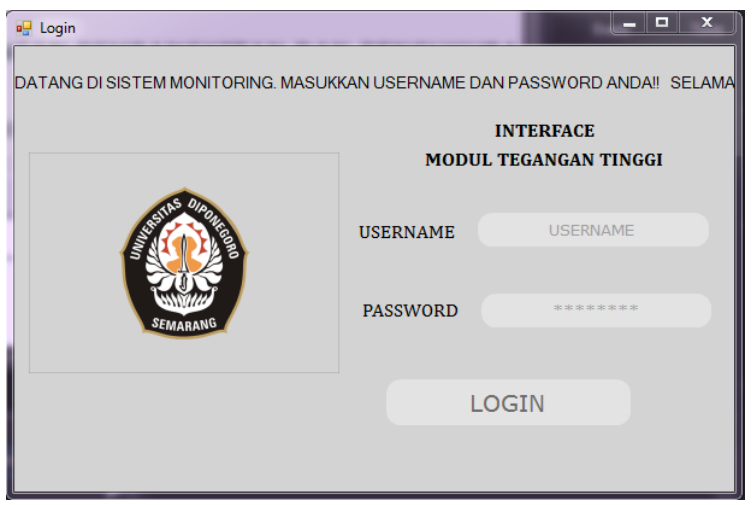

Gambar 8. Tampilan form Login

Untuk mengakses menu utama, user harus melakukan login terlebih dahulu dengan username "ELEKTRO14" dan password "ELEKTRO14". Jika login berhasil dilakukan maka akan muncul form Main dengan tampilan seperti pada Gambar 9.

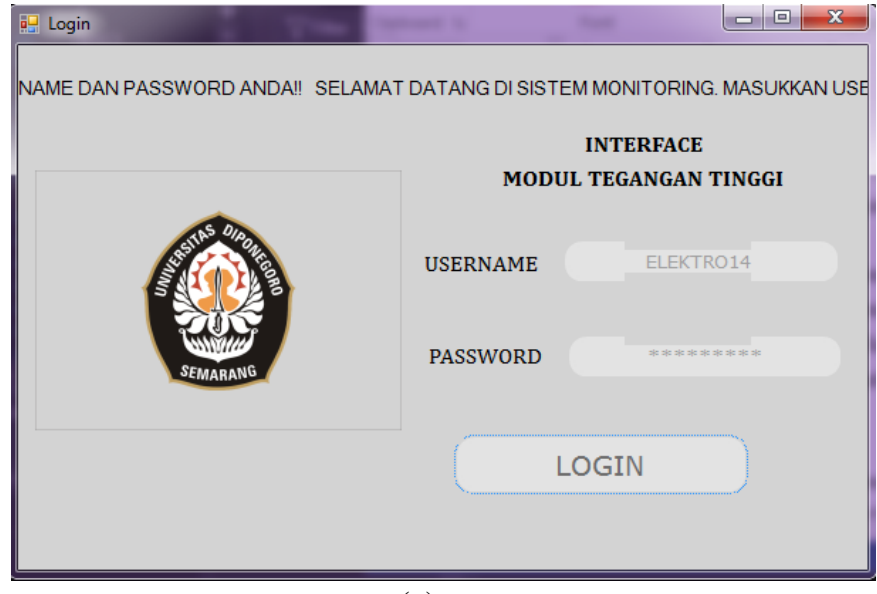

(a) 


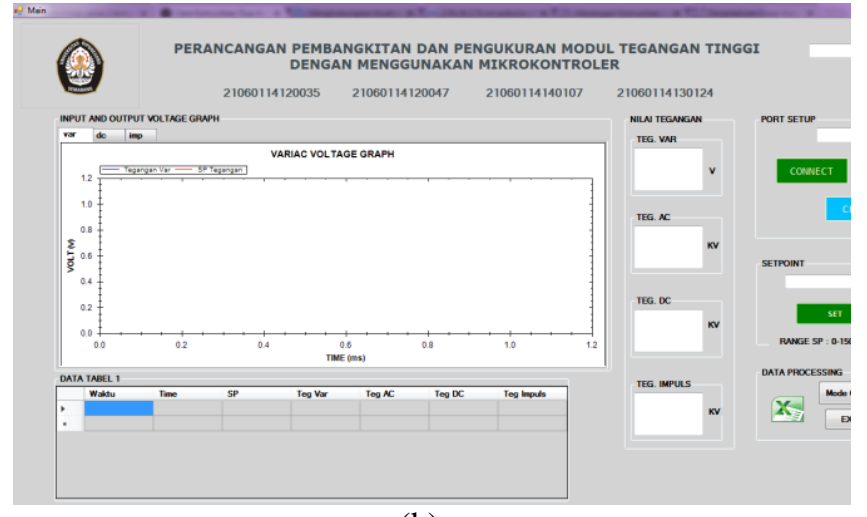

(b)

Gambar 10. (a) Form login dengan username dan password benar.

(b) Tampilan form main.

Jika login berhasil dilakukan maka akan otomatis masuk ke form main dengan tampilan seperti Gambar 10 (b).

2. Pengujian Username dan Password Salah

Pengujian username dan password salah dilakukan dengan mengisikan username dan password yang tidak sesuai. Hasil dari pengujian username dan password salah ditunjukkan pada Gambar 11

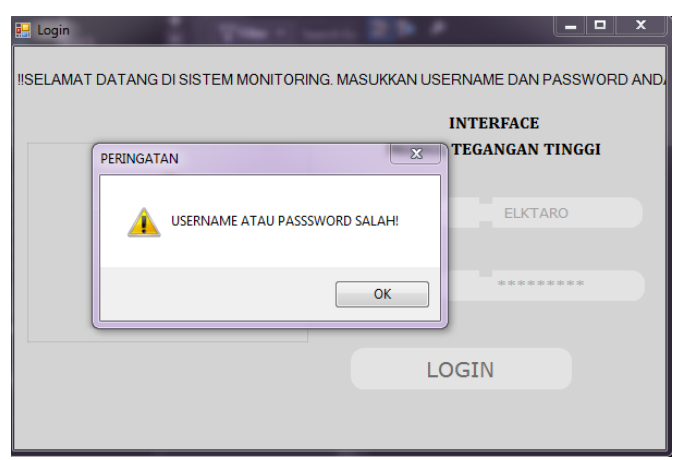

Gambar 11. Form login dengan username dan password salah.

\subsubsection{Pengujian Form Main}

Pada form main dilakukan pengetesan koneksi port, pemberian nilai setpoint, dan penyimpanan data tabel. Pada pengujian koneksi port, sebelumnya pastikan bahwa bluetooth dari pc dan dari mikrokontroler sudah terhubung. Gambar 12 menunjukkan hasil koneksi berhasil dan koneksi gagal.

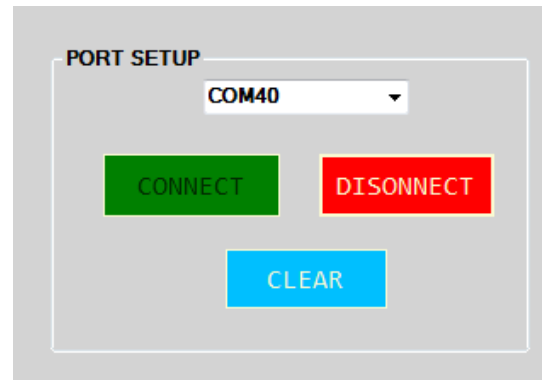

(a)

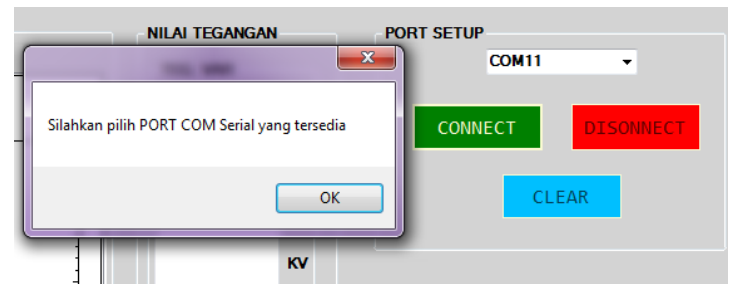

(b)

Gambar 12. (a) Tampilan koneksi berhasil terhubung (b) Tampilan koneksi gagal

Pada Gambar 12 (a) tombol connect akan berwarna lebih gelap bila bila berhasil terkoneksi. Apabila koneksi gagal maka akan muncul pemberitahuan seperti pada Gambar 12 (b).

Pengujian selanjutnya yaitu pemberian nilai setpoint. Apabila setpoint berhasil di set akan ditunjukkan tampilan seperti pada Gambar 13.

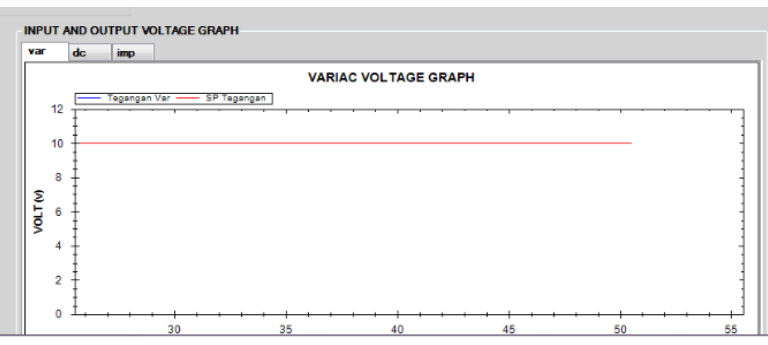

Gambar 13. Hasil pengujian pemberian nilai setpoint.

Pada Gambar 13 diatas dapat dilihat bahwa sistem sudah berjalan dan pada grafik sudah menunjukkan bahwa setpoint sudah sesuai dengan yang diberikan. Pengujian selanjutnya yaitu penyimpanan data berupa tabel. Gambar 14 menunjukkan hasil penyimpanan data tabel. 


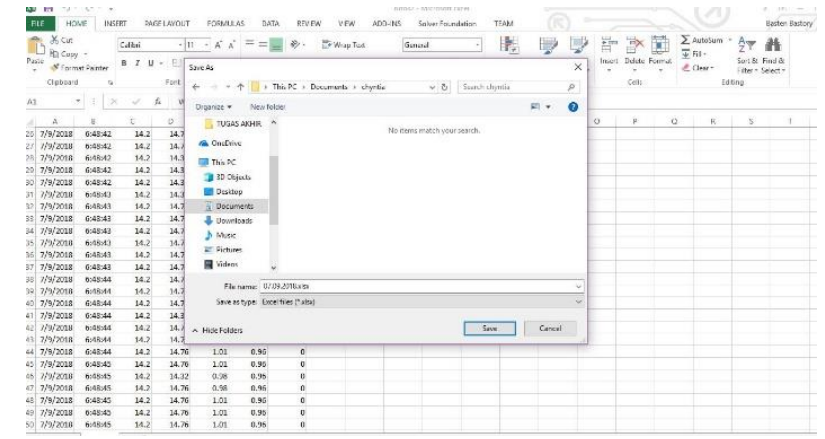

Gambar 14. Hasil penyimpanan data tabel.

Pada Gambar 14 dapat dilihat bahwa tabel sudah berhasil tereksport ke dalam penyimpanan excel. Jika berhasil tersimpan secara otomatis akan muncul pemilihan penyimpanan folder file.

\subsection{Pengujian Hasil Monitoring}

\subsubsection{Pengujian Tampilan Setpoint dan Variac}

Pada pengujian ini akan diamati tampilan hasil monitoring tegangan variac dan setpoint. Pengamatan meliputi hasil pada grafik dan pada tampilan tegangan. Setelah setpoint diberikan, variac akan merespon dengan bergerak menuju setpoint. Gambar 15 menunjukkan respon yang terjadi antara variac dan setpoint.

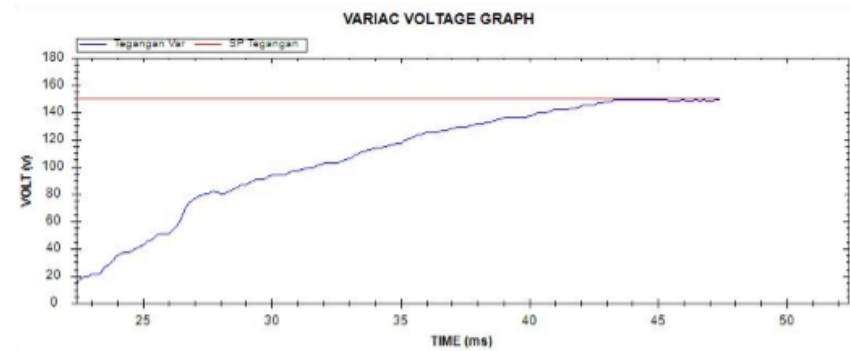

Gambar 15. Tampilan Grafik keluaran variac.

Dari Gambar 15 diatas dapat dilihat bahwa keluaran variac bergerak menuju setpoint yang diberikan. Maka dapat dikatakan bahwa tampilan variac bekerja dengan baik.

\subsubsection{Pengujian Tegangan Tinggi AC}

Hasil pengujian tegangan AC tegangan tinggi pada sistem monitoring data dapat dilihat pada Tabel 4.1.

Tabel 6. Hasil Pengujian AC.

\begin{tabular}{cccc}
\hline Variac (V) & $\begin{array}{c}\text { AC Monitoring } \\
(\mathbf{K V})\end{array}$ & $\begin{array}{c}\text { AC Terukur } \\
(\mathbf{K V})\end{array}$ & Error \\
\hline 11.63 & 0.8 & 0.82 & 0.02 \\
25.05 & 1.71 & 1.71 & 0 \\
39.82 & 2.57 & 2.56 & 0.01 \\
40.71 & 2.79 & 2.8 & 0.01 \\
\hline
\end{tabular}

Dari Tabel 6 diatas dapat dilihat bahwa semakin besar tegangan variac yang diberikan maka output tegangan AC terukur dan termonitoring sama-sama semakin besar. Ratarata Error yang terjadi antara tegangan AC terukur dengan tegangan AC monitoring relative kecil yaitu $0.01 \mathrm{~V}$. Dengan demikian dapat dikatakan bahwa program pembacaan tegangan AC tegangan tinggi berfungsi sebagaimana mestinya.

\subsubsection{Pengujian Tegangan Tinggi DC}

Hasil pengujian tegangan DC tegangan tinggi pada sistem monitoring data dapat dilihat pada Tabel 7.

Tabel 7. Hasil Pengujian DC.

\begin{tabular}{cccc}
\hline Variac $(\mathbf{V})$ & $\begin{array}{c}\text { DC Monitoring } \\
(\mathbf{K V})\end{array}$ & $\begin{array}{c}\text { DC Terukur } \\
(\mathbf{K V})\end{array}$ & Error \\
\hline 12.9 & 0.98 & 0.97 & 0.01 \\
25.6 & 1.95 & 2.02 & 0.07 \\
39.8 & 3.13 & 3.19 & 0.06 \\
50.7 & 3.98 & 4.03 & 0.05 \\
63.3 & 5.15 & 5.14 & 0.01 \\
74.5 & 6.19 & 6.14 & 0.05 \\
88.7 & 7.2 & 7.19 & 0.01 \\
101.2 & 8.22 & 8.21 & 0.01 \\
112.3 & 9.11 & 9.08 & 0.03 \\
126.7 & 10.3 & 10.02 & 0.01 \\
136.9 & 11.6 & 11.58 & 0.02 \\
155.7 & 12.7 & 12.6 & 0.01 \\
166.3 & 13.5 & 13.4 & 0.01 \\
176.7 & 14.5 & 14.3 & 0.02 \\
\hline
\end{tabular}

Dari Tabel 7 diatas dapat dilihat bahwa semakin besar tegangan variac yang diberikan maka output tegangan DC terukur dan termonitoring sama-sama semakin besar. Ratarata Error yang terjadi antara tegangan DC terukur dengan tegangan DC monitoring relatif kecil yaitu $0.028 \mathrm{~V}$. Dengan demikian dapat dikatakan bahwa program pembacaan tegangan DC tegangan tinggi berfungsi sebagaimana mestinya. Grafik keluaran dari tegangan tinggi DC dapat dilhat pada Gambar 16.

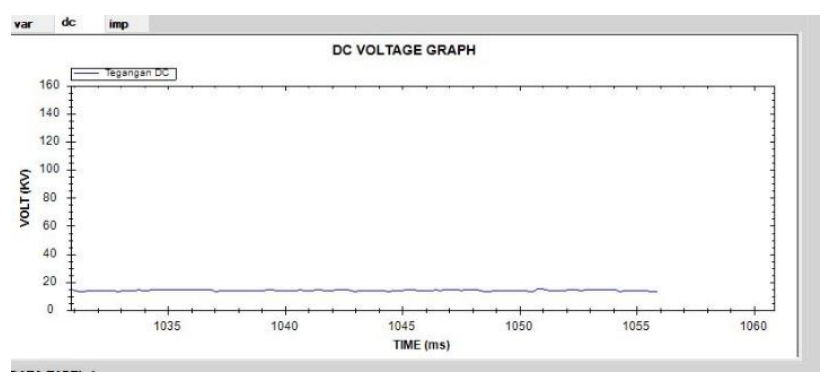

Gambar 16. Grafik keluaran tegangan tinggi DC.

Pada grafik diatas dapat dilihat bahwa keluaran tegangan DC mengalami kenaikan dan penurunan sesuai dengan tegangan yang dihasilkan. Hasil pembacaan tegangan secara lengkap akan dilampirkan pada lampiran.

\subsubsection{Pengujian Tegangan Tinggi Impuls}

Pengujian tegangan tinggi Impuls dilakukan dengan menggunakan resistor $680 \mathrm{~K} \Omega$. Pengujian dilakukan 
dengan dua cara yaitu dengan menggunakan osiloskop dan dengan sistem monitoring visual studio. Grafik hasil pengujian dapat dilihat pada Gambar 17

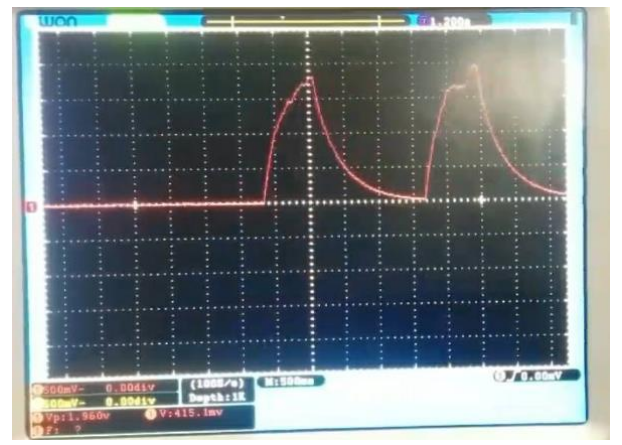

(a)

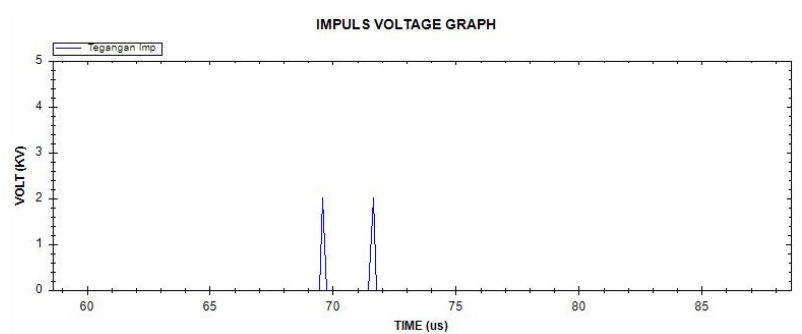

(b)

Gambar 17. (a) Grafik impuls dengan osiloskop.

(b) Grafik dengan visual studio

Pada Gambar 17 dapat dilihat bahwa grafik tegangan impuls pada osiloskop dan visual studio berbeda. Perbedaan ini terjadi karena time sampling pada osiloskop dan pada visual studio c\# berbeda. Selain itu fitur-fitur pada visual studio c\# juga memiliki batasan sehingga kurang bisa menampilkan dengan sempurna. Pada osiloskop dapat dilihat bahwa tegangan impuls yang dihasilkan yaitu $1.98 \mathrm{~V}$ sedangkan pada visual studio dapat dilihat bahwa tegangan impuls yang dihasilkan yaitu $2 \mathrm{~V}$. Hal ini menunjukkan bahwa program pengukuran tegangan tinggi Impuls berhasil dilakukan dimana ketika impuls terjadi sudah dapat terdeteksi pada grafik impuls visual studio c\#.

\section{Kesimpulan}

Berdasarkan hasil pengujian dan analisis yang dilakukan dapat disimpulkan bahwa telah dibuat alat monitoring pengukuran tegangan tinggi impuls dengan menggunakan Visual Studio C\#. Pada proses pengujian digunakan metode pembagi tegangan dan voltage to frequency dalam proses pengukuran tegangan. Pada pengukuran tegangan AC didapatkan hasil yang kurang memuaskan dikarenakan terjadi breakdown pada tegangan $6 \mathrm{KV}$. Pada pengukuran tegangan DC terjadi perbedaan tegangan dengan rata-rata $0.001 \mathrm{~V}$ antara pengujian dan pengukuran sebenarnya. Dan pada pengujian tegangan impuls didapatkan nilai Vp yaitu 2 KV. Pengujian ini masih belum sempurna karena pengukuran yang dilakukan sangat tidak stabil dikarenakan rentan terhadap noise.

\section{Referensi}

[1]. Abduh, Syamsir, "DASAR PEMBANGKITAN DAN PENGUKURAN", 2004.

[2]. Dean Emeritus, High Voltage Engineering Fundamentals Second edition, University of Manitoba, Caada.

[3]. Mujahid, Wildan, "Perancangan Pembangkit Tegangan Tinggi AC Frekuensi Tinggi Dengan Kumparan Tesla Menggunakan Inverter Jenis Push-Pull”, 2004.

[4]. Fitriandi, Afrizal, "Rancang Bangun Alat Monitoring Arus dan Tegangan Berbasis Mikrokontroler dengan SMS Gateway", ELECTRICIAN, 2016.

[5]. Suryawan, Dwi Wahyu, "RANCANG BANGUN SISTEM MONITORING TEGANGAN, ARUS DAN TEMPERATURE PADA SISTEM PENCATU DAYA LISTRIK DI TEKNIK ELEKTRO BERBASIS MIKROKONTROLER ATMEGA 128", 2012.

[6]. O. N. Dahl, "Optocoupler," Build Electronic Circuit. [Online]. Available: https://www.build-electroniccircuits.com/optocoupler/. [Accessed: 19-Agustus2018].

[7]. P. Scherz and S. Monk, Practical Electronics for Inventors 4th edition. McGraw Hill, 2016.

[8]. K. Paul, Analog to Digital Convertion using Voltage to Frequency Converter, AD-654.

[9]. S. Endang, dan S. Rika, "Perangkat Lunak HMI untuk Supervisory Control pada Plant Biodesel", P2 Informatika-LIPI, Mei 2012. 